\title{
Contributions of Paulo Freire to a Critical Data Literacy: a Popular Education Approach
}

Alan Freihof Tygel

Rosana Kirsch
Federal University of Rio de Janeiro, Brazil

Corresponding Author.

alantygel@ppgi.ufrj.br

EITA Cooperative, Brazil

rosana@eita.org.br

Paulo Freire is the patron of education in Brazil. His main work - the Popular Education pedagogy - influences many educators all over the world who believe in education as a way of liberating poor oppressed people. One of the outcomes of Freire's work is a literacy method, developed in the 1960's. In this paper, we propose the adoption of elements of Freire's Literacy Method for use in a pedagogical pathway towards data literacy. After tracing some parallels between literacy education and data literacy, we suggest some data literacy strategies inspired on Freire's method. We also derive from it a definition for critical data literacy.

\section{Introduction}

The introduction of new digital technologies to everyday life is an irrefutable reality. Information and communication technologies (ICTs) affect both those who have the infrastructure and education to enjoy the comfort brought by the ICTs and those who do not a social phenomenon known as the digital divide. The digital divide has been the subject of a developing field of study since the beginning of public Internet in the 1990's. This field includes the concept of digital inclusion as a way to overcome the inequalities of access to $\mathrm{ICTs}^{1}$.

Tygel, A.F., Kirsch, R. (2016). Contributions of Paulo Freire to a critical data literacy: a popular education approach. The Journal of Community Informatics, 12(3), 108-121.

Date submitted: 2016-01-04. Date accepted: 2016-06-06.

Copyright (C), 2016 (the authors as stated). Licensed under the Creative Commons AttributionNonCommercial-ShareAlike 2.5. Available at: www.ci-journal.net/index.php/ciej/article/view/1296

1 There is a vast literature about digital divide, which is out of the scope of this paper. For a very recent debate on this topic, we recommend Gurstein's paper Why I'm giving up on the digital divide (Gurstein, 2015). 
One fundamental step of digital inclusion is digital literacy, a term which draws a parallel between learning how to read and write - literacy - and learning how to use computers. With the growing presence of ICTs in society, specialized questions arise under digital literacy.

From the mid-2000s onwards, governments globally started to publish online big quantities of data (Chignard, 2013). It was the beginning of the worldwide movement towards open data, understood as the first step of a transparency process supporting democratic regimes. As a result of growing need, at the same time, the term data literacy started to be coined, although without a formal or widely accepted definition.

The promises brought by open data initiatives relate to a more transparent society, a deeper participative democracy, and possibilities of generating value from data (Huijboom \& Broek, 2011). Meanwhile, the severe social inequalities faced all over the world, reflected directly in the education level of the population, creates a strong potential for generating a mass of data illiterates.

In the 1960 's, in the northeast region of Brazil, the illiteracy rate - percentage of adult people who could not read or write - reached $72.6 \%$ (Ferraro \& Kreidlow, 2004). And precisely in that context arose the work of the philosopher Paulo Freire. He characterized the process of literacy education both as technically learning how to read and to write, and as the emancipatory process of understanding and expressing oneself in the world: "to learn how to read is to learn how to say the own word. And the own human word imitates the divine word: it creates." (Freire, 1987:11)

In this paper, we aim to trace parallels between the reflections of Freire about literacy education and the critical understanding of the world through data, using elements of Freire's work to comprehend the new phenomenon of data literacy. We propose a definition for critical data literacy, as a pedagogical methodology oriented to understand reality so as to transform it.

This is an introductory paper, with a number of limitations. The scarce literature about data literacy obliges us to bring inspiration from other sources, and is precisely in this sense that we seek the contributions of alphabet literacy methods to the field of data literacy. The ideas brought here are mostly in the theoretical field. Nevertheless, they came from concrete experiences in teaching open data (Tygel, Campos, \& Alvear, 2015) and developing information systems for social movements ${ }^{2}$. It should also be noted that Freire's development was driven in a specific context - teaching poor peasants how to read and write, with the intention of raising their consciousness - and thus, any adaptation of it for other contexts must take this into account.

\section{Paulo Freire, Literacy and Popular Education}

In Latin America, and especially in Brazil, the history of education cannot be told without the name of Paulo Freire. Born in Pernambuco, in 1921, he became worldwide famous for his critical pedagogy, and mostly for the development of the philosophical principles of the Popular Education, the most well known product of which is a literacy method.

2 The EITA Cooperative dedicates to developing ICTs for social movements. More on http:// www.eita.org.br. 
The first big experience of the application of the method happened in Angicos, a city in Rio Grande do Norte state in the northeast region of Brazil. In 1963, 300 sugar cane cutters became literate in 45 days, with 40 hours of classes. Subsequently, the then president of Brazil, João Goulart, invited Paulo Freire to organize a National Literacy Plan, with the goal of teaching more than 2 million people to read and write. The plan began in January 1964, but was quickly aborted by the civil-military coup, on the 1st of April 1964. Paulo Freire's method was replaced by the Brazilian Literacy Method (MOBRAL, in Portuguese), where all the critical view was removed. Paulo Freire was arrested and had to leave the country, returning only in 1980.

In the 1960's, the traditional literacy method was spread through primers, i.e., booklets containing the content to be taught. This was the central working tool for education, and the focus was on repeating loose words, and in creating decontextualised phrases to reinforce syllables and words. Some classic examples are shown in Table 1.

\begin{tabular}{|c|c|c|}
\hline $\begin{array}{r}\text { Phrase in } \\
\text { Portuguese }\end{array}$ & $\begin{array}{c}\text { Consonant } \\
\text { Highlighted }\end{array}$ & $\begin{array}{c}\text { Translation in } \\
\text { English }\end{array}$ \\
\hline Eva viu a uva. & $\mathrm{V}$ & Eva saw the grape. \\
\hline O boi baba. & $\mathrm{B}$ & The ox drool. \\
\hline A ave voa. & $\mathrm{V}$ & The bird flies. \\
\hline
\end{tabular}

Table 1: Decontextualised phrases used in traditional literacy method, in Brazil.

Freire said once that "it is not enough knowing that Eva saw the grape. It is necessary to comprehend what is the position of Eva in the social context, who worked to produce that grape, and who profited from this work" (Gadotti, 1996). Moreover, Eva is an extremely uncommon name in the northeast region of Brazil, and the grape is an uncommon fruit, grown typically in the south of the country. The statement is therefore completely decontextualised, and only encourages the students to memorize it, instead of understanding.

According to Freirean philosophy, the education must be contextualized, i.e., it should arise from the concrete experience of the educands ${ }^{3}$, and from what is familiar to them. The comprehension of reality does not occur through a mechanical relation between a sign - the written word - and a thing, but by the dialectical interaction subject-reality-subject, where signs and things relate themselves in a political, cultural and economic context. Therefore, the concepts Eva and grape should not be treated abstractly, but inside a context and a reality.

In a very simplified way, we can say Freire's Literacy Method has three stages (Schugurensky, 2014):

3 Some words used in this paper are specific from Freire's bibliography: educands (students), educators (teachers), thematisation and problematisation. Debating the origin of them is out of the scope of this work. 


\section{Investigation Stage}

In this first stage, the themes and words that compose the reality of the educands are defined. These themes must be part of the everyday life of the educands, and be very familiar to them. The prime idea behind the investigation stage is that the educational process must start from the educands' reality. Thus, educators are committed to dialogue with educands about themes that have to do with concrete aspects of their lives (Corazza, 2003). The generative themes are related to "the universe of speech, culture and place, which must be inquired, surveyed, researched, unveiled" (Brandão, 1985). The research of the vocabulary universe and the identification of keywords of the group or community are the base for developing the generative themes, and thus, for literacy education. They express limit situations, which, for Freire, are mostly oppressive situations (Corazza, 2003).

\section{Thematisation Stage}

This is the stage where the themes are coded and decoded, alongside the discussion about their social meaning in the world. The elaboration of thematic axes relates the generative theme with aspects of a particular or conjunctural reality, and at the same time, organizes the learning process in an articulated sequence. The thematic axes seek to interweave diagnostics and theoretical questions (Nuñez, 1998), fostering the dialectic sequence action-reflectionaction from the group involved in the learning process. As stated by (Freire, 2005), one way of dealing with thematic axes in the learning process is with the coding process, i.e., the representation of the world using symbols as language, drawing or images. Thus, decoding is the process of interpreting these codes. The decoding process generates new information through the production of more abstract higher level coding, based on the knowledge of the world possessed by each educand (Barato, 1984).

\section{Problematisation Stage}

In this stage, the focus is on questioning the meanings previously discussed, with the perspective of transforming reality. Reflection generates questions about myths surrounding one's own living reality (Freire, 1979). The reality manifested in the Investigation Stage, further coded and decoded, is then understood as something liable to be overcome.

When tackling Paulo Freire's Literacy Method, the Popular Education perspective must also be mentioned. As a whole educational philosophy, it is inspired by the stages of the literacy method, going deeper in its reflections. In the 1970's, many experiences of Popular Education in the South Cone - Chile, Argentina, Uruguay and Brazil - generated the reflection of this pedagogy as a permanent process of theorization over the practice in the context of the organization of the popular classes, mainly against dictatorships that were ruling these countries at that time (Jara, 1998). The process of collective construction of knowledge from generative themes and thematic axes, emerging from a lived reality, was named Systematization of Experiences. This should also be included as a fourth stage in the literacy method:

\section{Systematisation Stage}

In this stage, the lived experience is organized, interpreted and presented, in a communicative sense. Systematizing, more than gathering data and information about a context, is the 
exercise of theorizing about an experience and deeply analysing it. Systems of thought, information, management and action imposed by dominant powers promote a unique vision of the lived world, and this stage has the aim of elaborating an alternative view (Ghiso, 2011). The act of systematizing implies an evaluation of advances and innovations generated inside a collective experience, which can inspire other groups in other realities. The systematization of experiences presents itself as a method of investigation and "knowledge production, either from local experiences or wider participatory democracy practices, or other forms of political incidence." (Adams \& Streck, 2010).

\section{Parallels between Literacy Education and Data Literacy}

As data literacy is a new study domain, and thus under construction, there is no established definition for the term. According to the Data Journalism Handbook, "data literacy is the ability to consume for knowledge, produce coherently and think critically about data" (Grey, Bounegru, \& Chambers, 2012). Wikipedia states that "Data literacy is the ability to read, create and communicate data as information." Another work highlights the importance of understanding how to produce data (Carlson, Fosmire, Miller, \& Nelson, 2011). After discussing the parallels between both literacies, and the possible contributions of Paulo Freire to the topic, we derive our own definition of Data Literacy at the end of Section 4.

Before discussing what contributions from Freire can be brought to data literacy, it is necessary to trace some parallels between elements of popular education in general, Freire's Literacy Method in particular, and data literacy. In the following, we present three such parallels.

As stated above, literacy education is composed of two complementary and indivisible aspects: the technical ability of reading and writing, and the social emancipatory process of understanding and expressing oneself in the world. In data literacy, we can observe that there are technical capacities related to data manipulation, such as general computer abilities and statistical-mathematical methods, and capacities for critically analysing data, such as understanding the context in which they were generated, and the reality pictured by them.

Regarding the technical aspect, data literacy entails a higher technological complexity than alphabetization. Indeed, data literacy can only happen among literate people. While the literacy education process only requires a book, a pencil and a paper, the data literacy education normally requires computers, mobile devices, and internet connection. Mathematical reasoning skills are also fundamental to this process. So, we can affirm that data literacy is a technically more complex process than literacy education.

We can also say that there are deep differences in social exclusions caused by each kind of illiteracies. According to the Brazilian statistical agency, in $20138.5 \%$ of the population older than 15 years was illiterate. A closer look reveals a high correlation with poverty and regional inequality. In the northeast region, the poorest of the country, the index almost doubles: $16.6 \%$. The rural slice reveals an even higher index: $18.6 \%$ of countryside residents are illiterate. Therefore, a correlation between illiteracy, socio-economic standing, and geographical location can be observed. 
Lack of data literacy - "data illiteracy", if we can already refer to this term - covers a much larger slice of the population and results in more subtle disadvantages, which however tend to get stronger as far as the open data policies advance. Gurstein (2011) cites two examples where data illiterates were severely affected by the publication of land ownership records as open data, one in Nova Scotia, Canada and another in Bangalore, India. By not having access to data, in both cases, small farmers lost their land to other landowners who checked inconsistencies in the land records and judicially claimed their ownership. The small farmers were elderly and illiterate, and thus also data illiterate. This example supports the work of Boaventura de Sousa Santos (2006), who demystifies the idea that the cyberspace and its informations lie in a decentralized and free access space. For the author, the cyberspace evinces the computer apartheid generated by social inequalities.

\begin{tabular}{|l|l|l|l|}
\hline Stage & Literacy & Data Literacy & Result \\
\hline Investigation & $\begin{array}{l}\text { Understanding of educand's context, and } \\
\text { discovery of socially relevant themes in that } \\
\text { reality }\end{array}$ & $\begin{array}{l}\text { Survey of vocabulary } \\
\text { universe: source for } \\
\text { generative themes } \\
\text { and thematic axes. }\end{array}$ \\
\hline Thematisation & $\begin{array}{l}\text { Coding and decoding } \\
\text { of words and } \\
\text { understanding of its } \\
\text { social meaning }\end{array}$ & $\begin{array}{l}\text { Coding of the themes } \\
\text { into existing (or not) } \\
\text { data, and decoding } \\
\text { for understanding } \\
\text { realities }\end{array}$ & $\begin{array}{l}\text { Generative theme } \\
\text { and thematic axis } \\
\text { coded as images, } \\
\text { film or data }\end{array}$ \\
\hline Problematisation & $\begin{array}{l}\text { Finding } \\
\text { contradictions } \\
\text { surrounding the } \\
\text { decoded themes, and } \\
\text { demystifying the } \\
\text { realities }\end{array}$ & $\begin{array}{l}\text { Discovering non- } \\
\text { neutrality in data: } \\
\text { which aspects are } \\
\text { exposed by data, and } \\
\text { which are hidden? }\end{array}$ & $\begin{array}{l}\text { Critical view about } \\
\text { the themes }\end{array}$ \\
\hline Systematisation & $\begin{array}{l}\text { Organization, } \\
\text { interpreting, and } \\
\text { presentation of the } \\
\text { lived experience }\end{array}$ & $\begin{array}{l}\text { Organizing and } \\
\text { interpreting reality } \\
\text { through data, and } \\
\text { communicating } \\
\text { discoveries }\end{array}$ & $\begin{array}{l}\text { Communication } \\
\text { products }\end{array}$ \\
\hline
\end{tabular}

\section{A Freirean Inspired Critical Data Literacy}

In the following, we present an exercise of adapting key-concepts of Freire's Literacy Method to what we are going to call critical data literacy. At the end of this section, we derive our own definition for the term. Table 2 shows, in a systematic form, the stages of the literacy method and its possible specializations for data literacy.

Table 2: Relation between Freire's Literacy Method and data literacy

\section{The Emancipatory Character of Data Literacy}

As in Freire's method, our data literacy approach has an emancipatory perspective. The literacy concept, as stated above, can be analysed in two dimensions: the technical abilities and the emancipation achieved through the literacy process. Given the high technical complexity of data manipulation, there seems to be a natural tendency for this dimension to suppress the emancipatory one. Immersed in studies involving the use of computers, specialized software, various data sources and statistical methods, there might be a tendency of the educands to leave behind the critical reflection about the social meanings of data in the 
world, and therefore the emancipatory perspective may be put in background. The emancipatory perspective resulting from data literacy can be manifested in certain abilities acquired by the educands, for example:

Context interpretation: Critical analysis of a specific reality can be more consistently performed based on benchmarking and statistics. As an example, we can cite the topic of land concentration in Brazil. Anyone living rurally in Brazil knows that a few landowners control huge amounts of land. This empirical perception can be better supported if we analyse the agricultural census, which shows that $45 \%$ of the arable land is controlled by $1 \%$ of landowners, making Brazil one of the countries with the most concentrated land possession in the world.

Questioning of common sense concepts: Many concepts understood as "truth" are built upon data. However, the comprehension about how this data was generated allows a critical eye on these concepts. One example is the concept of Gross Domestic Product (GDP), generally used to distinguish the economic importance of different countries. Although regarded as the most important measure of a country's economy, it does not consider the income distribution or the environmental consequences of economic development.

Development of new concepts: Through consistent generation of data, it is possible to enlighten invisible realities and establish new concepts. For example, in 2007, a mapping revealed that almost 2 million people in Brazil worked in self-managed cooperatives, within a solidarity economy context. This data sheds light on other forms of work organization, which normally are hidden or considered small experiments, and allows the establishment of the idea of other possible economic arrangements.

\section{Data Literacy Process}

Figure 1 shows our proposed critical data literacy process. At the first stage (i), the group observes some context, seeking for elements in common with their reality. Through this view, it is possible to define what kind of data - existing or to be collected - can support and enhance this view. At this stage (ii), data from this context is gathered. The critical analysis of this data (iii) is necessary in order to understand which perspectives are illuminated by this data, and which are hidden. Finally, after the critical analysis of data, it is possible to look again to the context (iv), see it from another perspective and act towards its transformation. It is important to notice that this is not a linear process, but an iterative one. The last step is always an enhanced realization of the first, and the process should be continued until the objectives are achieved.

Figure 1: Data literacy process

It is also worth noting that this process is very similar, in its conception, to Participatory Action-Research (PAR) (Morin, 2004). This methodological paradigm associates a transforming action with every research intervention, the planning and application of which should always be carried out with the researched subjects. One of the main references of PAR in Brazil is the work of Michel Thiollent, who suggests that action research

consists in coupling action and research in a process, in which the implied actors participate, together with the researchers, to interactively elucidate the reality in 


\section{Subjects}

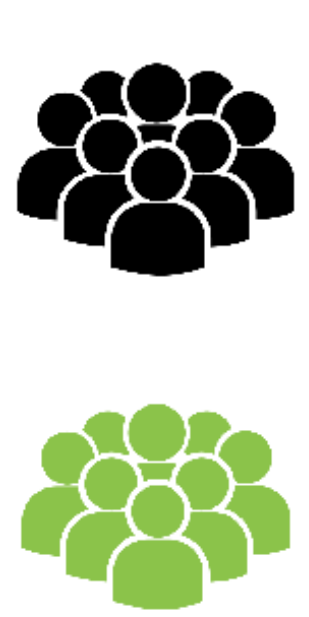

(iii) Critical analysis of data

\section{(i) View of the \\ reality}

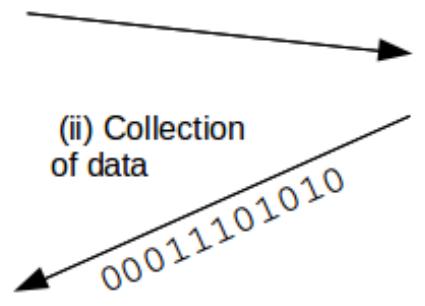

(iv) Modified view and action upon the reality

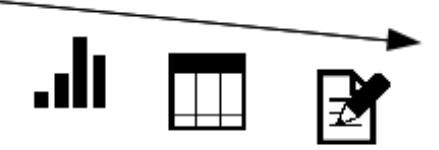

\section{Context}
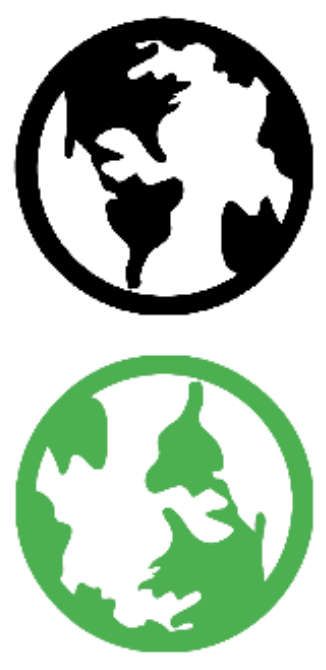

which they are inserted, identifying collective problems, seeking and experimenting solutions in real situations. Simultaneously, there is production and use of knowledge. (Thiollent, 2009: 14)

\section{Data Literacy Stages}

\section{Investigation}

As already stated, this stage must guarantee that the educational process effectively starts from the educand's reality. Just like the grape is not a typical fruit from the northeast region of Brazil, a database is also probably not something that is explicitly part of the everyday life of data educands. (Their personal data, however, are almost definitely registered in one or more databases.) At the same time, it is important to seek in the reality of each educand elements where data can be useful to understand that reality. Considering possible problems in dealing with computers, it is fundamental that the themes to be worked with are of great interest to educands, and have their foundations in daily life. It is also important to find contradictions in this reality that one desires to overcome. Thus, an interesting way of starting this quest is through statistics. For example, as detailed in Tygel et al. (2015), in a data literacy course, the educands were exposed to statistical information previously selected about their realities. From this point on, it was shown that, on the one hand, datasets were already part of their life, and on the other hand, that much information known by the educands was omitted by data. Thereby, a data mediated world view is approached, facilitating the most adequate choice of thematic axis to work with.

\section{Thematisation}

At this stage, the main goal is to motivate the understanding of the world through data. Either for a local or global reality, about specific or generic themes, data allows an understanding of reality commonly seen as "neutral" or "objective". At the thematisation stage, it is still possible to keep this aspect, which will be further deconstructed in the problematisation stage. 
By elaborating thematic axes, in this stage the aim is to code certain contexts as data and aggregated information, such as statistics, graphics and tables. This coding may lead to more complex decoding about the same theme. A reality can be coded into data, which can be once more coded into aggregated information, and then can be further decoded, generating a modified view over the same reality. It is always important to notice that this process has an intrinsic bias, related to the design choices at data acquisition and processing.

As a result of this stage, it is possible to obtain the generative themes, which in the case of data literacy, are specific context coded into data. This data can be already available as open databases, closed and subject to information access requests, or may also be uncollected data, which could provide some interesting perspectives. The final aim of this stage is to enchant educands with the world of data that represents realities.

\section{Problematisation}

After the "enchantment" with the world of data, it is fundamental to problematise it, i.e., to unveil what is behind the scenes when talking about data. In order to use data with critical consciousness, it is necessary to know where they came from, how and to what purpose they were generated. Thus, it is possible to politicise the use of data, and deal with them not only from the point of view of a passive user, but from the perspective of someone who is also able to produce data, and with them, "say his word". The final aim of this stage is to promote a critical view about the chosen theme, understanding the role of data for enlightening certain aspects and hide others. We list here, without aspirating to completeness, two issues that can serve as a starting point for the problematisation stage:

\section{1) Non-neutrality of Data}

Data are not neutral. The seducing precision and objectivity of data grounded statements almost always hide ideologies and intentions about anything one wants to prove. Thus, it is fundamental to problematise the origin of data. Are data from the government or from civil society organizations? What was the political position of that organization at the time when data were generated? If it is about scientific data, who funded the research? More complex, but also of great importance, is the knowledge of the methodology used to gather data. Lack of awareness of the methodological approach can lead to misunderstandings and flawed conclusions.

With that information - origin and method - it is possible to infer what was the objective of data generation, where it is not explicit. Producing data is a costly activity, which requires a considerable amount of resources, especially when dealing with big populations and/or wide areas. Therefore, every research that generates data has a very well defined purpose, which must be unveiled and discussed.

Research is designed by specific actors, to reach strategic goals. Similarly, methodologies are designed in order to highlight some aspects, and not others. This is why we can affirm that data resulting from these researches are not neutral, and therefore its non-neutrality must be problematised in a critical perspective of data literacy education. 


\section{2) Transparency}

In many cases, the critical use of data will come across the lack of available data. These missing data may not exist, be hidden or poorly organized, which is the case for a lot of government data. In order to work critically with data, it is necessary to be aware of one's rights to access information, which is directly related to transparency policies. Many countries are advancing in this field, publishing their data online and creating laws to guarantee access to information, transparency and open data, with the valuable argument of enhancing democracy and fighting corruption. However, as stated by the Global Open Data Index, only $11 \%$ of the assessed datasets in 97 countries are open. Thus, discussing transparency and access to information is a possible way of problematising data literacy.

\section{3) Systematisation}

The systematisation process requires data and information about an experience. In the data literacy context, the ability to put together data retrieved from various external sources with subjective qualitative information empirically obtained should be encouraged.

The systematizing stage should be the conclusion of the whole lived process - investigation, thematisation and problematisation. Of crucial importance is the communication of the results. Data can be exposed in several forms, such as graphics, tables, maps, infographics, music, film or even text. The ability to choose the right way of systematizing and communicating data is certainly a point that should be stressed in data literacy.

\section{Definition}

Considering the arguments developed in this section, we derive our definition of critical data literacy:

Critical Data Literacy is the set of abilities which allows one to use and produce data in a critical way. This set is composed by:

Data reading: The ability to read data starts with understanding how the data was generated, i.e., which methodologies were used to capture the data from a context, which facts, measures and dimensions were considered, and at which level of detail, or granularity, data was collected. It also includes understanding who produced it, in which context and why. Data should not be read as objective fact, but as the output of a social process.

Data processing: The ability to technically process data is related to the use of computational and statistical tools in order to transform data into information. Linking data with other sources is also an important skill. Data should be processed based on explicit objectives.

Data communication: The ability to communicate data comprises finding better matches between data types, such as distributions, temporal series, networks or comparisons, and communications tools, such as text, tables, different types of charts, maps or infographics combining these elements. Communicating data also encompasses a social evaluation of what message should be transmitted to which target audience. Data communication should be done in an ethical, responsible and precise way, in order to avoid misunderstandings or invalid conclusions. 
Data production: The ability to produce data includes deepening all elements within data reading. Additionally, knowledge about data formats and data publishing tools is required. Generally, data should be published not only respecting the Open Definition, but also offering tools so that non-experts are able to use it.

\section{Related Works}

It can be said that Data Literacy has its roots on other related fields, such as Information Literacy and Statistical Literacy. The relation between these three literacies was emphasized by Schield (2004), who reinforced the importance of teaching these three literacies for "students who need to critically evaluate information in arguments".

Data literacy initiatives started to be driven a few years ago, and have been pushed mostly by civil society organizations, although there have also been governmental efforts. The initial state of this movement is reflected in the academic literature, especially when dealing with popular education. The popular education approach for dealing with data literacy is still limited in the available literature.

One exception is a blog post by Bhargava, in 2013, trying to relate the popular education of Freire with data literacy. The author introduces the concept of popular data, presenting a synthesis of popular education and its' relationship with appropriation and use of data for decision taking. For him, governments are talking about data, but most of the people are not understanding the conversation. He cites an initiative by the of city of Somerville, in Massachusetts, and its ResiStat program, which regularly promotes meetings with the community and stimulates the civic participation via Internet through discussions and databased decisions. He concludes from this initiative that people can only participate if they have an understanding of tables, graphics and terms related to data. The perspective of popular data, for Bhargava, is oriented by participatory approaches for using data and decision taking that provokes engagement of the population.

Expanding from data to wider ICTs and the relation to popular education, a work by Adams and Streck (2010) affirms the focus of popular education on social transformations through the action-reflection-action of marginalized and oppressed classes. The authors develop their work by questioning the role of ICTs in the production of the current structural conditions, and whether these technologies have the potential for pedagogical mediation seeking the construction of new paradigms. They critically conclude that there are several studies related to education that do not recognize the digital technologies as pedagogical mediations, but as mere tools. According to them, this approach is reductionist, because the pedagogical mediation happens between people through their lived realities, reflecting about it and transforming it. The knowledge production through systematization of experiences and participatory research is emphasized, with a focus on reflection about lived experiences. ICTs, for the authors, "compose a structural reality which conform behaviours, ways of thinking and acting which tends to adapt, modify, recreate and assume emancipatory paradigms". At the same time, technologies are not neutral and their limits have to be tested, with a constant critical vigilance, and thus popular education cannot but put in the background.

According to Ferreira \& Santos (2002), there is a potential for changes in education caused by the wide access to information and knowledge through cyberspace. One of the challenges is to 
collectively build knowledge between educators and educands, overcoming "bureaucratic separations of authorships between who elaborates, who applies, who clarifies, and who manages the education process". Authors compare the unidirectional and the interactive approach in the education field. In the first case, the teacher delivers knowledge and the students have a passive reception role. In the second approach, the complex knowledge network emerged in an educative environment is recognized, and both educators and educands can be authors and co-authors. The concept of co-authorship is recommended to be applied as a praxis to be developed both in on-site and distance education.

\section{Conclusions}

The fast spreading of ICTs in the society has, as one of its consequences, a recent publication of massive quantities of data over the Web. These can be either related to governments, through public transparency initiatives, or generated by companies or civil society organizations, or even originated from scientific research. This huge mass of new information brings with it a series of potential benefits, but also major challenges, which are for the most part not as explicit as the benefits. There is an imminent risk of establishing an elite able to profit from these data, interpret it and act in the world through it, while most of the people remain excluded. In this paper, we sought in the work of Paulo Freire inspirations for the construction of a critical data literacy, which incorporates awareness of this challenge.

Future works on this topic includes deriving more tangible examples of the application of this methodology in practice, followed by developing a strategy to assess and evaluate the outcomes. From the theoretical point of view, a deep analysis of the digital, information and statistics literacy literature could also bring more elements for our field.

Regarding critical data literacy, a yet unexplored source of inspiration may come from epistemology of the south and decolonization theories. Authors such as Carlos Walter PortoGonçalves, Linda Tuhiwai Smith, Vandana Shiva or Boaventura Santos emphasize the autonomy of traditional communities in developing their own research methodologies and produce data in order to overcome their invisibility. This should certainly be regarded as a data literacy process.

Another important discussion is related to the chance of including Critical Data Literacy as part of formal educational programmes at primary level, adapting the methodology described in Tygel et. al. (2015). This would be a very important step in order to prepare new digital natives to deal critically with data. An ethical challenge would be posed for those in charge of preparing Critical Data Literacy curriculum and driven related activities.

\footnotetext{
$* * *$
}

It was not by accident that Paulo Freire materialized his Popular Education pedagogy into a literacy method. For him, literacy is not only useful to read words, but to read the world. And imbued precisely by this spirit, we propose an analysis of data literacy based on Freire's Literacy Method. By doing so, we hope to provide a small contribution to the democratization of access to information. Data alone do not change the world, but we believe that people who critically understand the reality through data have better tools to do it. 


\section{Acknowledgements}

A. Tygel is supported by CAPES/PDSE grant 99999.008268/2014-02.

This paper is an extension of the paper "Contributions of Paulo Freire for a critical data literacy", written by the same authors, and published at the I Data Literacy Workshop, Oxford, 2015.

We would also like to thank Maria Luiza Machado Campos, Uschi Silva, Johanna Walker, Mark Frank and the anonymous reviewers for the valuable contributions.

\section{References}

Adams, T., \& Streck, D. R. (2010). Educação Popular e novas tecnologias. Educação, 33(2), 119-127.

Barato, J. N. (1984). Codification/decodification: an experimental investigation on the adult education theory of Paulo Freire. San Diego State University. Retrieved from https://jarbas.wordpress.com/ 048-codificacaodecodificacao-em-paulo-freire/

Brandão, C. R. (1985). O que é o método Paulo Freire. São Paulo: Brasiliense.

Carlson, J., Fosmire, M., Miller, C. C., \& Nelson, M. S. (2011). Determining Data Information Literacy Needs: A Study of Students and Research Faculty. Libraries Faculty and Staff Scholarship and Research, 11(2), 629-657. http://doi.org/10.1353/pla.2011.0022

Chignard, S. (2013). A Brief History of Open Data. Retrieved January 16, 2014, from http:// www.paristechreview.com/2013/03/29/brief-history-open-data/

Corazza, S. M. (2003). Tema Gerador: concepção e prática. Ijuí: Editora Unijuí.

Ferraro, A. R., \& Kreidlow, D. (2004). Analfabetismo no Brasil: configuração e gênese das desigualdades regionais. Educação E Realidade, 29(2), 179-200.

Ferreira, S. de L., \& Santos, E. O. dos. (2002). Formação de professores e cibercutltura: novas práticas curriculares na educação presencial e a distância. In IV ANPED-Sul Seminário de Pesquisa em Educação da Região Sul (Vol. 1). Florianópolis: UFSC.

Freire, P. (1979). Educação e Mudança (12th ed.). Rio de Janeiro: Paz e Terra.

Freire, P. (1987). Pedagogia do Oprimido (11th ed.). Editora Paz e Terra.

Freire, P. (2005). Pedagogy of the Oppressed (30th ed.). New York: Continuum. http://oi.org/ 10.1007/BF02195128

Gadotti, M. (1996). Paulo Freire: Uma Biobibliografia. São Paulo: Cortez Editora/Instituto Paulo Freire.

Ghiso, A. M. (2011). Sistematización: un pensar el hacer que se resiste a perder su autonomia. Decisio, $1(28), 3-8$.

Grey, J., Bounegru, L., \& Chambers, L. (2012). Data Journalism Handbook. OKFN.

Gurstein, M. B. (2011). Open data: Empowering the empowered or effective data use for everyone? First Monday, 16(2), 1-7.

Gurstein, M. B. (2015). Why I'm Giving Up on the Digital Divide. Journal Of Community Informatics, 11(1). Retrieved from http://ci-journal.net/index.php/ciej/article/view/1210/1139 
Huijboom, N., \& Broek, T. Van Den. (2011). Open data: an international comparison of strategies. European Journal of ePractice, 1(12), 1-13.

Jara, O. (1998). Los desafíos de la educación popular. In Metodología de La Educación Popular. La Habana: Asociación de Pedagogos de Cuba.

Morin, A. (2004). Pesquisa-Ação Integral e Sistêmica: Uma Antropopedagogia Renovada (1st ed.). Rio de Janeiro: DP\&A.

Nuñez, C. (1998). Educar para transformar, transformar para educar. In Metodología de La Educación Popular. La Habana: Asociación de Pedagogos de Cuba.

Santos, B. de S. (2006). A Gramática do Tempo - Para uma Nova Cultura Política - Col. Para um Novo Senso Comum - Vol. 4. Cortez.

Schield, M. (2004). Information Literacy, Statistical Literacy and Data Literacy. IASSIST Quarterly Summer/Fall, 28(2/3), 6-11. Retrieved from http://citeseerx.ist.psu.edu/viewdoc/summary? doi=10.1.1.144.6309

Schugurensky, D. (2014). Paulo Freire. London: Bloomsbury Publishing.

Thiollent, M. (2009). Pesquisa-ação nas organizações (2nd ed.). São Paulo: Atlas.

Tygel, A. F., Campos, M. L. M., \& Alvear, C. A. S. de. (2015). Teaching Open Data for Social Movements - a Research Methodology. Journal of Community Informatics, 11(3). Retrieved from http://ci-journal.net/index.php/ciej/article/view/1220/1165 